\title{
Pojęcie duchownego w świetle przepisów dotyczących zawarcia małżeństwa wyznaniowego ze skutkami cywilnoprawnymi
}

\begin{abstract}
Artykuł opisuje pojęcie duchownego uprawnionego do dokonania różnego typu czynności prawnych związanych z zawarciem małżeństwa. Małżeństwo przed duchownym w polskim systemie prawnym reguluje 11 ustaw określających stosunki Państwa Polskiego ze związkami wyznaniowymi. Postanowienia tych aktów prawnych pozwalają na wstąpienie w wyznaniowy związek małżeński ze skutkami cywilnoprawnymi. Ważność małżeństwa uzależniona jest od upoważnienia duchownego do udzielenia ślubu. Artykuł udziela odpowiedzi na pytanie kto może przyjąć oświadczenie woli od przyszłych małżonków oraz sporządza zaświadczenie o zawarciu małżeństwa do Urzędu Stanu Cywilnego w każdym związku wyznaniowym.
\end{abstract}

\section{Wstęp}

Podstawowym przepisem regulującym kwestię zawarcia małżeństwa wyznaniowego ze skutkami cywilnymi jest art. 1 § 2 i 3 Kodeksu rodzinnego i opiekuńczego' ${ }^{1}$. Przywołany artykuł stanowi o podmiotach posiadających legitymację do zawarcia małżeństwa oraz odebrania od nich oświadczeń woli o wstąpieniu w związek małżeński. W jego świetle kobieta i mężczyzna zawierają związek małżeński podlegający prawu wewnętrznemu kościoła lub innego związku wyznaniowego w obecności duchownego. Wyrażają tym samym wolę sformalizowania związku podlegającego polskiemu prawu, w wyniku czego właściwy kierownik Urzędu Stanu Cywilnego sporządza akt małżeństwa. Możliwość udzielania ślubów posiadają kościoły i inne związki wyznaniowe, które na mocy ratyfikowanej umowy międzynarodowej bądź ustawy regulującej stosunki Państwa do danego kościoła lub związku wyznaniowego (w dalszej części opracowania zwane jako „ustawy wyznaniowe”) otrzymały uprawnienie do połączenia ceremonii wyznaniowej wraz ze świecką.

\footnotetext{
${ }^{1}$ Ustawa z 25.2.1964 r. - Kodeks rodzinny i opiekuńczy, tekst jedn. Dz.U. z 2017 r. poz. 682, dalej jako k.r.o.
} 


\section{Wpływ podpisania Konkordatu na polski system prawa}

Kodeks rodzinny i opiekuńczy wprowadza do polskiego systemu prawnego pojęcie „duchownego". Pojawiło się ono w momencie, kiedy przyjęcie art. 10 Konkordatu z 1993 r. ${ }^{2}$ nie pozwalało na praktyczne zastosowanie procedury w nim zawartej. Niemniej umożliwiło doprecyzowanie formy zawarcia małżeństwa w aktach niższego rządu ${ }^{3}$. Zabieg ten, w odniesieniu do małżeństwa nupturientów będących wiernymi Kościoła Katolickiego, realizuje art. 25 Konstytucji Rzeczpospolitej Polskiej ${ }^{4}$, stanowiący o równouprawnieniu kościołów i innych związków wyznaniowych w Polsce. W związku z możliwością zawarcia małżeństwa wyznaniowego, wywołującego jednocześnie skutki na gruncie prawa cywilnego, pojawiła się potrzeba nowelizacji wspominanych przepisów. Przed znowelizowaniem przepisów Kodeksu rodzinnego i opiekuńczego i innych aktów prawnych, na mocy ustawy z 26.6.1997 r. o zmianie ustawy o gwarancjach wolności sumienia i wyznania oraz o zmianie niektórych ustaw $^{5}$ dokonano zmian w ustawach wyznaniowych. Dodano między innymi przepisy stwarzające możliwość wywierania skutków cywilnych poprzez zawarcie małżeństwa podlegającego prawu wewnętrznemu danego kościoła lub związku wyznaniowego. Tym samym cywilna forma zawarcia małżeństwa przestała być jedynym sposobem, dzięki któremu sformalizowanie związku małżeńskiego przez nupturientów wywierało skutki przewidziane w prawie cywilnym.

We wszystkich ustawach wyznaniowych przepisy zostały przyjęte w niemal identycznym brzmieniu; określają, że małżeństwo zawarte w formie przewidzianej prawem wewnętrznym danego związku wyznaniowego wywołuje skutki cywilne, o ile zostały spełnione warunki określone w Kodeksie rodzinnym i opiekuńczym. Ponadto ustawy wyznaniowe wskazują osobę uprawnioną do odebrania od nupturientów oświadczeń woli o wstąpieniu w związek małżeński. Dodano regulacje stwierdzające, że osobę duchowną przed którą składane jest owo oświadczenie, określa prawo wewnętrzne danego kościoła lub związku wyznaniowego.

Tak przyjęta regulacja co do istoty zawarcia małżeństwa wyznaniowego nałożyła na osoby duchowne dodatkowe obowiązki, wynikające $\mathrm{z}$ ich ,podwójnej roli”.

\footnotetext{
${ }^{2}$ Konkordat między Stolicą Apostolską a Rzeczpospolitą Polską z 28.7.1993 r., Dz.U. 1993, Nr 51 poz. 318.

3 M. Osuchowska, Pojęcie duchownego $w$ świetle przepisów o wyznaniowej formie zawarcia matżéstwa cywilnego, Państwo i Prawo 2011, nr 7-8, s. 67; ustawa z 24.7.1998 r. o zmianie ustaw - Kodeks rodzinny i opiekuńczy, Kodeks postępowania cywilnego, Prawo o aktach stanu cywilnego, ustawy o stosunkach Państwa do Kościoła Katolickiego w Rzeczpospolitej Polskiej oraz niektórych innych ustaw, Dz.U. 117, poz. 757.

${ }^{4}$ Konstytucja Rzeczpospolitej Polskiej z 2.4.1997 r., Dz.U. 1997, Nr 78, poz. 483.

${ }^{5}$ Dz.U. Nr 59, poz. 375.
} 
Pełnią oni nie tylko funkcję przedstawicieli danego związku wyznaniowego, ale poniekąd stają się urzędnikami państwowymi ${ }^{6}$. Duchowny jest wówczas świadkiem kwalifikowanym zdarzenia prawnego, jakim jest zawarcie małżeństwa przez nupturientów.

\section{Pojęcie duchownego w świetle przepisów Kodeksu rodzinnego i opiekuńczego oraz ustawy - Prawo o aktach stanu cywilnego}

Wraz $\mathrm{z}$ określeniem procedury zawierania małżeństwa $\mathrm{w}$ formie wyznaniowej ustawodawca zobowiązany został do wprowadzenia do systemu prawnego legalnej definicji pojęcia „duchownego". Po raz pierwszy dokonał tego w ustawie - Prawo o aktach stanu cywilnego $^{7}$, w której wskazano, że minister właściwy do spraw wewnętrznych (uprzednio minister właściwy do spraw administracji) na podstawie informacji otrzymanych od przedstawicieli kościołów i innych związków wyznaniowych, ogłosi w Dzienniku Urzędowym Rzeczpospolitej Polskiej „Monitor Polski” wykaz stanowisk, które są upoważnione do przyjmowania oświadczeń o wstąpieniu w związek małżeński oraz sporządzania zaświadczeń, będących podstawą do sporządzenia aktu małżeństwa ${ }^{8}$. Pierwszy tego typu wykaz został opublikowany w obwieszczeniu MSWiA z 4.11.1998 r.

Niezwykle trudno zbudować jedną, jednoznaczną i uniwersalną definicję „duchownego" na podstawie prawa wewnętrznego jedenastu kościołów i związków wyznaniowych, które uzyskały możliwość do udzielania ślubów wyznaniowych, wywierających jednocześnie skutki prawa cywilnego. Dla ujednolicenia w przepisach prawnych przyjęto, że termin „duchowny” oznacza osobę właściwą do spełniania roli świadka kwalifikowanego, który asystuje przy zawieraniu małżeństwa 9 . Jednocześnie jednak normy prawne odsyłają do uregulowań prawa wewnętrznego danego kościoła bądź związku wyznaniowego, celem zidentyfikowania owego świadka. W tym przypadku duchowny uprawniony do asystowania staje się podmiotem prywatnym, któremu przez państwo zostały zlecone zadania z dziedziny administracji publicznej.

Nowelizacja Kodeksu rodzinnego i opiekuńczego z 1998 r. wprowadziła pojęcie „duchownego" i kilkukrotnie jest ono używane w tym akcie prawnym. Pojawia się między innymi w art. $1 \S 2$ k.r.o. wskazując, że duchowny jest świadkiem kwalifikowanym,

\footnotetext{
${ }^{6}$ B. Górowska, Realizacja konkordatu polskiego w latach 1998-2008 [w:] C. Janik, P. Borecki (red.), Dziesięć lat polskiego konkordatu, Warszawa 2010, s. 98.

${ }^{7}$ Ustawa z 28.11.2014 r. - Prawo o aktach stanu cywilnego, tekst jedn. Dz.U. z 2016 r. poz. 2064 ze zm.

${ }^{8}$ Zob. art. 91 ustawy z 28.11.2014 r. - Prawo o aktach stanu cywilnego.

${ }^{9}$ M. Osuchowska, Pojęcie duchownego..., s. 68.
} 
którego obecność jest niezbędna do zawarcia związku małżeńskiego wyznaniowego. Artykuły 8 i k.r.o. nakładają jednak na duchownego dodatkowo różne obowiązki wynikające z możliwości wywołania skutków cywilnych. W myśl art. 8 k.r.o. obowiązany jest on w pierwszej kolejności do zapoznania się z zaświadczeniem właściwego kierownika Urzędu Stanu Cywilnego o braku okoliczności wyłączających możliwość zawarcia małżeństwa przez nupturientów. Dodatkowo w świetle art. 9 k.r.o. duchowny, w razie niebezpieczeństwa grożącego bezpośrednio życiu jednej ze stron, został uprawniony do odebrania od narzeczonych chcących zawrzeć związek małżeński zapewnienia, iż nie wiedzą o żadnych okolicznościach wyłączających możliwość zawarcia przez nich małżeństwa, zamiast zaświadczenia wydanego przez kierownika USC. Duchowny ma obowiązek sporządzenia zaświadczenia stwierdzającego złożenie oświadczeń woli o zawarciu małżeństwa wyznaniowego ze skutkami cywilnymi w jego obecności. Ostatnim jego zadaniem jest, w myśl art. $8 \quad \S \quad 3$ k.r.o., złożenie $\mathrm{w}$ terminie pięciu dniu owego dokumentu do Urzędu Stanu Cywilnego ${ }^{10}$.

Pojęcie „duchownego” używane jest przez ustawodawcę w różnym kontekście i trudno jest je jednoznacznie zdefiniować. Artykuł $8 \S 1$ k.r.o. odwołuje się do art. $1 \S 2$ k.r.o., w myśl którego duchownym jest osoba w rozumieniu, jakie zostało przyjęte przez ustawy wyznaniowe. Inaczej jest w przypadku $\S 3$ przywołanego artykułu, w którym termin „duchowny” rozumiany ma być w kontekście art. 91 ust. 2 ustawy - Prawo o aktach stanu cywilnego. Trudno natomiast jednoznacznie określić, w jakim znaczeniu funkcjonuje analizowane pojęcie w art. $8 \S 2$ k.r.o.; przepis odwołuje się do paragrafu poprzedzającego, stanowiąc, że duchowny sporządza zaświadczenie stwierdzające wyrażenie woli przez małżonków o zawarciu małżeństwa w jego obecności. W związku z tym należy skłonić się do poglądu, że pojęcie „duchownego" jest tu definiowane tak, jak w ustawach wyznaniowych.

Warto zauważyć, że nie zawsze duchowny odbierający oświadczenia woli od nupturientów jest jednocześnie upoważniony do sporządzenia zaświadczenia będącego podstawą do rejestracji związku w Urzędzie Stanu Cywilnego. Wobec powyższego termin „duchowny” nie może być rozumiany w takich przypadkach w znaczeniu używanym w art. 91 ustawy - Prawo o aktach stanu cywilnego. Zróżnicowanie to można dostrzec na przykładzie obwieszczenia Ministra Spraw Wewnętrznych ${ }^{11}$.

\footnotetext{
${ }^{10}$ M. Osuchowska, Pojęcie duchownego..., s. 69.

${ }^{11}$ Zob. Obwieszczenie Ministra Spraw Wewnętrznych z 5.2.2015 r. w sprawie ogłoszenia wykazu stanowisk, których zajmowanie upoważnia do przyjmowania oświadczeń o wstąpieniu w związek małżeński oraz
} 
Artykuł $8 \S 2$ k.r.o. stanowi o podpisaniu oświadczenia o wstąpieniu w związek małżeński przez duchownego, małżonków oraz dwóch pełnoletnich świadków, obecnych przy złożeniu tych oświadczeń. W tym przypadku pojęcie „duchownego” może odnosić się zarówno do osoby odbierającej oświadczenia woli od małżonków, jak i osoby sporządzającej zaświadczenia o zawarciu małżeństwa ${ }^{12}$. Należy mieć także na względzie fakt, że nie zawsze - w myśl prawa wewnętrznego kościoła lub innego związku wyznaniowego osoba odbierająca od nupturientów oświadczenia woli o wstąpieniu w związek małżeński może sporządzić zaświadczenie o zawarciu małżeństwa, a to z uwagi na stosowne upoważnienia i delegacje do podpisania dokumentu.

Kolejna trudność w zdefiniowaniu pojęcia „duchownego” wiąże się z rozstrzygnięciem kto jest uprawniony do dostarczenia zaświadczenia o zawarciu małżeństwa do Urzędu Stanu Cywilnego. Ustawodawca na dokonanie tej czynności przewidział pięciodniowy termin od dnia zawarcia związku ${ }^{13}$. Problem ten pojawi się zwłaszcza w momencie, gdy zaświadczenie nie dotrze w wyznaczonym okresie do Urzędu Stanu Cywilnego bądź z innych powodów termin na dokonanie tej czynności nie zostanie zachowany. Według przedstawicieli doktryny, w takich przypadkach odpowiedzialność spoczywa na duchownym, który w świetle prawa został zobowiązany do sporządzenia dokumentu.

Ustawodawca w sposób wyraźny określa, kto w danym kościele lub innym związku wyznaniowym może zostać upoważniony do jego przygotowania ${ }^{14}$. Do przygotowania zaświadczenia stanowiącego podstawę do sporządzenia aktu małżeństwa uprawnieni są ${ }^{15}$ :

a) w Kościele Katolickim - ordynariusz miejsca (biskup diecezjalny, administrator apostolski, administrator diecezji, wikariusz generalny, wikariusz biskupi), biskup polowy, proboszcz, administrator parafii, wikariusz lub inny duchowny odpowiednio delegowany w zastępstwie proboszcza,

b) w Polskim Autokefalicznym Kościele Prawosławnym - biskup, proboszcz, wikariusz w zastępstwie proboszcza,

\footnotetext{
sporządzania zaświadczeń stanowiących podstawę sporządzenia aktu małżeństwa zawartego w sposób określony w art. $1 \S 2$ i 3 Kodeksu rodzinnego i opiekuńczego (M.P. 2015. 230).

12 A. Mezglewski, Pojęcie ,duchownego” w przepisach prawa polskiego o zawarciu małżeństwa, [w:] Studia z Prawa Wyznaniowego 2001, Tom II, s. 22.

${ }^{13}$ Zob. art. 8 3 k.r.o. w zw. z art. 87 ust. 5 ustawy - Prawo o aktach stanu cywilnego.

${ }_{14}$ T. Smyczyński, Odpowiedzialność odszkodowawcza duchownego z powodu naruszenia prawa przy zawieraniu matżeństwa, RPEiS nr 2002, nr 2, s. 165-177.

${ }^{15}$ Zob. Obwieszczenie Ministra Spraw Wewnętrznych z 5.2.2015 r. w sprawie ogłoszenia wykazu stanowisk, których zajmowanie upoważnia do przyjmowania oświadczeń o wstąpieniu w związek małżeński oraz sporządzania zaświadczeń stanowiących podstawę sporządzenia aktu małżeństwa zawartego w sposób określony w art. $1 \S 2$ i 3 Kodeksu rodzinnego i opiekuńczego (M.P. 2015. 230).
} 
c) W Kościele Ewangelicko-Augsburskim - proboszcz, proboszcz pomocniczy z upoważnienia proboszcza, proboszcz-administrator, wikariusz z upoważnienia proboszcza albo proboszcza-administratora,

d) w Kościele Ewangelicko-Reformowanym - proboszcz, administrator parafii

e) w Kościele Ewangelicko-Metodystycznym - pastor parafii,

f) w Kościele Chrześcijan Baptystów - pastor,

g) w Kościele Adwentystów Dnia Siódmego - duchowni starsi,

h) w Kościele Polskokatolickim - biskup ordynariusz, administrator diecezji, proboszcz parafii, administrator parafii,

i) w Związku Gmin Wyznaniowych Żydowskich - rabin, podrabin,

j) w Kościele Starokatolickim Mariawitów - biskup, proboszcz, administrator,

k) w Kościele Zielonoświątkowym - pastor.

Mimo obowiązywania normatywnego katalogu, w praktyce w dalszym ciągu pojawiają się problemy i wątpliwości odnoszące się do legitymacji osób uprawnionych do sporządzenia dokumentu. Takie nieścisłości dotyczą na przykład Kościoła Katolickiego, i osoby „duchownego w zastępstwie proboszcza”. To nieprecyzyjne sformułowane przysparza trudności nawet przy próbie określenia jego znaczenia w oparciu o prawo kanoniczne. Wskazuje jednak na to, że w Kościele Katolickim funkcjonuje zezwolenie do udzielania upoważnień każdemu duchownemu, bez względu na obywatelstwo czy miejsce pełnienia posługi ${ }^{16}$. Podobna sytuacja ma miejsce $w$ innych związkach wyznaniowych i utrudnia to sprawę o tyle, że kierownik Urzędu Stanu Cywilnego nie ma możliwości sprawdzenia czy duchowny, którego podpis widnienie na zaświadczeniu o zawarciu małżeństwa, faktycznie asystował przy jego zawieraniu oraz był upoważniony do dokonania tej czynności. Wiedza taka nie stanowi także podstawy do odmowy wydania aktu małżeństwa ${ }^{17}$.

\section{Pojęcie duchownego w świetle ustaw wyznaniowych}

W tej części opracowania dokonana zostanie analiza prawa wewnętrznego kościołów i innych związków wyznaniowych, mających uregulowane stosunki z Rzeczpospolitą Polską. Jest to niezbędne dla identyfikacji osoby uprawnionej do asystowania przy zawieraniu małżeństwa przez narzeczonych oraz sporządzenia oświadczenia o zawarciu przez nich związku małżeńskiego.

\footnotetext{
${ }^{16}$ A. Mezglewski, A. Tunia, Wyznaniowa forma zawarcia małżeństwa cywilnego, Warszawa 2007, s. 100.

${ }^{17}$ M. Osuchowska, Pojęcie duchownego..., s. 71.
} 


\subsection{Kościół Katolicki}

Ustawa z 17.5.1989 r. o stosunku Państwa do Kościoła Katolickiego w Rzeczpospolitej Polskiej ${ }^{18} \mathrm{w}$ art. $15 \mathrm{a}$ ust. 2 stanowi, że „osobę duchowną, przed którą składa się oświadczenie o zawarciu małżeństwa określa prawo kanoniczne”. W prawie wewnętrznym Kościoła Katolickiego, w kan. $207 \S 1$ Kodeksu Prawa Kanonicznego ${ }^{19}$ pojawia się zapis, że wśród wiernych występują szafarze święci, których prawo nazywa również duchownymi. Tytuł III Kodeksu Prawa Kanonicznego poświęcony został tematyce kształcenia duchownych, inkardynacji (przynależności) duchownych, praw i obowiązków oraz przypadkach warunkujących utratę stanu duchownego.

Zgodnie z Kodeksem Prawa Kanonicznego do duchownych zalicza się osoby, które przyjęły co najmniej świecenia diakonatu. Warto zaznaczyć, że w Kościele Katolickim istnieją trzy rodzaje święceń: diakonat, prezbiterat oraz biskupstwo ${ }^{20}$. Duchownym staje się mężczyzna, który przyjął sakrament święceń. Uprawnieni do asystowania przy zawieraniu małżeństwa na terenie swojej parafii są natomiast: ordynariusz miejsca ${ }^{21}$, proboszczowie i administratorzy parafii. Wikariuszom parafialnym nie przyznaje się takiego uprawnienia, mogą jednak ją posiadać na podstawie prawa partykularnego ${ }^{22}$. Jurysdykcja opiera się na zasadzie terytorializmu, co oznacza, że osoba uprawniona do asystowania nie może ważnie dokonać tej czynności poza swoją diecezją bądź parafią ${ }^{23}$. Wspomniana jurysdykcja do asystowania przy zawieraniu małżeństwa może być jednak przekazana na podstawie udzielnej delegacji, przez osobę posiadającą ową władzę $\mathrm{z}$ mocy prawa, ze względu na zajmowane stanowisko. Delegacja jest swoistym pełnomocnictwem i może być udzielona jako ogólna, bądź też do określonych przypadków (szczególna), przy czym warto zauważyć, że delegacja ogólna powinna być udzielona w formie pisemnej, natomiast szczególna w sposób dorozumiany $^{24}$. Jurysdykcja stanowi podstawę do uznania małżeństwa za ważnie zawarte

\footnotetext{
${ }^{18}$ Ustawa z 17.5.1989 r. o stosunku Państwa do Kościoła Katolickiego w Rzeczpospolitej Polskiej, tekst jedn. Dz.U. 2018 r., poz. 380.

19 Zob. Dekret nr 48/84/P. - Kodeks Prawa Kanonicznego (Kanon.1983.12.4), www.trybunal.mkw.pl/Kodeks\%20Prawa\%20Kanonicznego.pdf, [dostęp: 15.1.2018 r.].

${ }^{20}$ Zob. kan. 1008, kan. 1009.

${ }^{21}$ Kan. 134 Kodeksu Prawa Kanonicznego określa kim w rozumieniu prawa wewnętrznego jest ordynariusz miejsca tj. Biskup Rzymski, biskupi diecezjalni, inni, którzy są przełożonymi Kościoła partykularnego lub wspólnoty do niego przyrównanej zgonie z przepisem kan. 368, jak też ci, którzy posiadają wykonawczą władzę zwyczajną - wikariusze generalni i biskupi.

22 A. Mezglewski, Pojęcie ,„duchownego”,..., s. 8.

${ }^{23}$ S. Kasprzak, Wybrane zagadnienia z Prawa Kościelnego, Lublin 2000, s. 700.

${ }^{24}$ Delegacja nie może być udzielona w sposób domniemany, nawet w sytuacji braku reakcji osoby uprawnionej do delegowania, przy dokonywaniu oczywistych czynności przez osobę nieuprawnioną wskazujących na
} 
w świetle przepisów prawa kanonicznego, jak i k.r.o., w związku ze wspomnianym już obwieszczeniem Ministra Spraw Wewnętrznych.

\subsection{Polski Autokefaliczny Kościół Prawosławny w RP}

Ustawa o stosunku Państwa do Polskiego Autokefalicznego Kościoła Prawosławnego ${ }^{25}$ wyjaśnia w art. 12a ust. 2, że osobę duchowną, przed którą nupturienci składają oświadczenie woli o wstąpieniu w związek małżeński, określa prawo wewnętrzne Kościoła. Termin „prawo wewnętrzne” (pisane małymi literami) wskazuje na brak jednego skodyfikowanego zbioru prawa wewnętrznego tego Kościoła. Statut Wewnętrzny Polskiego Autokefalicznego Kościoła Prawosławnego ${ }^{26}$ nie określa osoby, która jest uznawana za duchownego w prawie wewnętrznym tego Kościoła. Nie wskazuje również, kto ma delegację do prawnie ważnego asystowania przy zawieraniu związku małżeńskiego. Zasady odnoszące się do zawierania małżeństwa wynikają jedynie $\mathrm{z}$ założeń teologiczno-doktrynalnych Kościoła ${ }^{27}$. Podstawami prawnymi w tym przypadku są zbiory starożytnych tekstów tj.: Kanony Apostolskie, Kanony siedmiu soborów powszechnych, kanony soborów lokalnych i prowincjonalnych, które uzyskały powszechną akceptację oraz kanony Ojców Kościoła ${ }^{28}$. Dopiero zbiór tych dokumentów określa się mianem Prawa Wewnętrznego Polskiego Autokefalicznego Kościoła Prawosławnego. W oparciu o przywołane teksty do stanu duchowieństwa zaliczani są: biskupi, kapłani i diakoni. Zgodnie z przywołanymi w tych aktach zasadami, uprawnionymi do asystowania przy zawieraniu małżeństwa są jedynie biskupi i kapłani. Diakoni zostali wyłączeni w sprawowaniu tej funkcji. Wynika to z przekonania, że „sakrament udzielany jest dwojgu ludziom w Ciele Kościoła przez kapłańskie błogosławieństwo" 29 . Duchowny jest więc osobą udzielającą sakramentu, a nie asystującą przy zawieraniu małżeństwa. W konsekwencji nie jest dopuszczalne udzielenie delegacji do asystowania, nawet w sytuacji nadzwyczajnej.

\footnotetext{
asystowanie przy zawieraniu małżeństwa, nieingerowanie nie oznacza zatem udzielenia delegacji. Zob. T. Pawluk, Prawo kanoniczne wedlug Kodeksu Jana Pawła II, T.III. Prawo matżeńskie, Olsztyn 1984, s. 179.

${ }^{25}$ Ustawa z 4.7.1991 r. o stosunkach Państwa do Polskiego Autokefalicznego Kościoła Prawosławnego, Dz.U. 2014, poz. 1726.

26 Statut Wewnętrzny Polskiego Autokefalicznego Kościoła Prawosławnego z 10.2.1995 r., Warszawa; http://www.old.diecezjawroclawsko-szczecinska.pl/przydatne/Statut_PAKP.pdf. [dostęp: 15.1.2018 r.]

${ }^{27}$ A. Mezglewski, Pojęcie ,,duchownego"..., s. 10.

${ }^{28}$ H. Hrycuniak, Prawostawne pojmowanie malżeństwa, Białystok 1994, s. 88; § 2 Statutu Wewnętrznego Polskiego Autokefalicznego Kościoła Prawosławnego.

${ }_{29}$ J. Meyendorff, Matżeństwo w Prawostawiu. Liturgia, teologia, życie., Lublin 1995, s. 155.
} 


\subsection{Kościół Ewangelicko-Augsburski w RP}

Podobnie do innych ustaw wyznaniowych, ustawa o stosunku Państwa do Kościoła Ewangelicko-Augsburskiego w Rzeczpospolitej Polskiej ${ }^{30}$ w art. 12a ust. 2 wskazuje, że osoby uprawnione do asystowania przy zawieraniu małżeństwa wyznaniowego określa Zasadnicze Prawo Wewnętrzne Kościoła Ewangelicko-Augsburskiego w Polsce ${ }^{31}$. Przepisy $§ 17$ i 18 tego aktu stanowią, że „Kościół posiada urząd zwiastowania Słowa Bożego i sprawowania Sakramentów". Tytuł duchownego uzyskiwany jest na podstawie ordynacji. W myśl § 18 Zasadniczego Prawa Wewnętrznego urząd posiada trzy posługi: biskupa, prezbitera i diakona. Według natomiast $\S 17$ ust. 2 duchowni z tytułu ordynacji są równi w zwiastowaniu Słowa Bożego i sprawowaniu Sakramentów. Uregulowanie $§ 36$ ust. 3 Zasadniczego Prawa Wewnętrznego określa w sposób wyraźny, kto jest uprawniony do przyjmowania oświadczeń woli o zawarciu małżeństwa wywołujących skutki cywilnoprawne. Są to: biskupi, proboszczowie oraz wikariusze. Szczegółowe przepisy zawarte zostały w Pragmatyce Służbowej Kościoła Ewangelicko-Augsburskiego w Rzeczpospolitej Polskiej32. W § 121 tego dokumentu uznaje się, że „małżeństwo zostaje zawarte, gdy mężczyzna i kobieta jednocześnie obecni (...), złożą wobec uprawnionego duchownego zgodne oświadczenie woli jego zawarcia oraz ślubowanie wierności małżeńskiej”. Szczegółową regulację w tym względzie ujmuje § 122 Pragmatyki, w którym mowa o obecności przy ślubowaniu ordynowanego duchownego oraz dwóch świadków. W tym świetle duchowny, który będzie obecny przy zawieraniu małżeństwa, musi być ordynowany, czyli posiadać niezbędne uprawnienie do asystowania. Osobą uprawnioną będzie proboszcz parafii bądź też inny duchowny w jego zastępstwie ${ }^{33}$. Zgodnie z $§ 36$ Pragmatyki diakoni również są uprawnieni do udzielania ślubów kościelnych, na prośbę proboszcza.

\subsection{Kościół Ewangelicko- Reformowany w RP}

\footnotetext{
${ }^{30}$ Ustawa z 13.5.1994 r. o stosunku Państwa do Kościoła Ewangelicko-Augsburskiego w Rzeczypospolitej Polskiej, tekst jedn. Dz.U. z 2015 r., poz. 43.

${ }^{31}$ Zasadnicze Prawo Wewnętrzne Kościoła Ewangelicko- Augsburskiego w Rzeczpospolitej Polskiej z 26.10.1996 r., http://luteranie.pl/files/prawo_koscielne/zpw.pdf. [dostęp: 15.01.2018 r.]

32 Pragmatyka Stużbowa Kościoła Ewangelicko-Augsburskiego $\quad$ z $\quad 21.10 .1998 \quad$ r., http://www.chorzow.luteranie.pl/wp-content/uploads/2014/10/Pragmatyka-sluzbowa.pdf. [dostęp: 15.1.2018 r.]

33 Zob. § 124,125 Pragmatyki, w których mowa o proboszczu parafii narzeczonej, uprawnienie innego duchownego wynika z możliwości delegowania zawarcia małżeństwa na inny teren, za pisemną zgodą proboszcza.
} 
Według prawa wewnętrznego w Kościele Ewangelicko-Reformowanym wśród służby kościoła są: diakoni, duchowni, doktorzy i starsi. Jednocześnie, na podstawie Prawa Wewnętrznego Kościoła Ewangelicko-Reformowanego ${ }^{34}$ uznaje się, że „duchownym może być osoba wyznania ewangelicko-reformowanego, która po ukończeniu akademickich studiów teologicznych, odbyciu przepisanego stażu oraz złożeniu pierwszego egzaminu konsystorskiego została ordynowana według formy wskazanej w agendzie" (art. 51). Artykuł 52 Prawa Wewnętrznego 'zrównuje' wszystkie stanowiska kościelne wskazując, że ,wszyscy duchowni bez względu na zajmowane stanowisko, są sobie równi i używają tytułu księdza". Ustawa o stosunku Państwa do Kościoła Ewangelicko-Reformowanego w Rzeczpospolitej Polskiej ${ }^{35} \mathrm{w}$ art. 8a ust. 2 stanowi, że osobę duchowną, która jest uprawniona do odebrania oświadczeń woli od nupturientów, określa Prawo Wewnętrzne Kościoła. Przepisy wewnętrze nie definiują jednak pojęcia „duchownego”, uprawnionego do przyjęcia wspomnianych oświadczeń woli.

\subsection{Kościół Ewangelicko-Metodystyczny w RP}

Stosunki Rzeczpospolitej Polskiej z Kościołem Ewangelicko-Metodystycznym określa ustawa o stosunku Państwa do Kościoła Ewangelicko-Metodystycznego ${ }^{36}$. W Prawie Wewnętrznym Kościoła Ewangelicko-Metodystycznego ${ }^{37}$ za duchownych uznaje się: diakonów, którzy są duchownymi młodszymi oraz prezbiterów, jako duchownych starszych $^{38}$. Według art. 12 Prawa Wewnętrznego diakonem może zostać członek Kościoła, który ma ukończone 21 lat, jest stanu wolnego lub żyje w związku małżeńskim (warunkiem wyłączającym jest rozwód), ukończył studia teologiczne, seminarium teologiczne lub inne studia uznane przez Konferencję za równorzędne, dodatkowo został przyjęty przez Zgromadzenie Duchownych na próbę, podczas której odbył studium konferencyjne z wynikiem dodatnim oraz posiada nieposzlakowaną opinię. Studium trwa od dwóch do czterech lat. Następnie składa egzaminy przed Radą Wykształcenia Pastorskiego.

\footnotetext{
34 Prawo wewnętrzne Kościoła Ewangelicko-Reformowanego $\quad$ w $\quad$ RP $\quad$ z $\quad 5.5 .1991 \quad$ r., http://www.ekumenizm.wiara.pl/doc/478725.Prawo-wewnetrzne-Kosciola-EwangelickoReformowanego-W. [dostęp: 15.1.2018 r.]

${ }^{35}$ Ustawa z 13.5.1994 r. o stosunku Państwa do Kościoła Ewangelicko-Reformowanego w Rzeczpospolitej Polskiej, tekst jedn. Dz.U. z 2015 r., poz. 483.

${ }^{36}$ Ustawa z 30.6.1995 r. o stosunku Państwa do Kościoła Ewangelicko-Metodystycznego w Rzeczypospolitej Polskiej, tekst jedn. Dz. U. z 2014 r., poz. 1472.

37 Prawo Wewnętrzne Kościoła Ewangelicko-Metodycznego w Rzeczpospolitej Polskiej z 25.5.1991 r.; https://www.metodyscipomorze.files.wordpress.com/2017/02/prawo-wewnc499trzne.pdf. [dostęp: 15.1.2018 r.]

${ }^{38}$ Zob. art. 11 Prawa wewnętrznego Kościoła Ewangelicko-Metodycznego.
} 
Jeśli ich wyniki są pozytywne, Komisja Kwalifikacji i Święceń Pastorskich bada czy dany kandydat posiada moralne kwalifikacje oraz opiniuje jego podanie o przyjęcie do grona diakonów. Kandydatów zatwierdza Zgromadzenie Duchownych, natomiast ordynacja dokonywana jest przez Biskupa. Artykuł 13 Prawa Wewnętrznego reguluje kto może zostać starszym duchownym, czyli prezbiterem. Jest to „diakon, który odbył kolejne, dwuletnie studium konferencyjne, zakończone po każdym roku egzaminem z pozytywnym wynikiem, złożonym przed Radą Wykształcenia Pastorskiego, otrzymał dodatnią kwalifikację od Komisji Kwalifikacji i Święceń Pastorskich i został zatwierdzony przez Zgromadzenie Duchownych”. Podobnie, jak w przypadku diakonów, starszy duchowny jest ordynowany przez Biskupa. Oprócz tego funkcje religijne sprawują kaznodzieje miejscowi oraz diakonise. W myśl art. 18 Prawa Wewnętrznego kaznodzieja miejscowy może zostać wyznaczony do pełnienia obowiązków pastora, $\mathrm{z}$ wyłączeniem prawa do sprawowania sakramentu Wieczerzy Pańskiej. Jest to jedyne ograniczenie, w związku z tym należy domniemywać, że uprawnień tego duchownego należy również asystowanie, w szczególnych przypadkach, przy zawieraniu małżeństwa.

\subsection{Kościól Chrześcijan Baptystów w RP}

Zasadnicze Prawo Wewnętrzne Kościoła Chrześcijan Baptystów ${ }^{39}$ w art. 47 ust. 1 stanowi, że duchownymi są: pastorzy, misjonarze, diakoni i wikariusze. Według ust. 2 wspomnianego artykułu ,duchowny powinien reprezentować wysokie biblijne kwalifikacje duchowe, moralne i intelektualne dając rękojmię prawidłowego wykonywania zadań duszpasterskich i misyjnych, posiadający dogłębną znajomość Pisma Świętego". W myśl art. 48 Zasadniczego Prawa Wewnętrznego pastor jest duchownym ordynowanym, przy czym ust. 5 wskazuje, że ordynacja na urząd pastora dokonywana jest przez dwóch pastorów, którzy działają z upoważnienia Rady Kościoła”. Dodatkowo dla pastorów szczególnie zasłużonych dla Kościoła, na mocy art. 48 ust. 6, Konferencja Zboru może przyznać tytuł prezbitera. Według art. 50 i 52 Zasadniczego Prawa Wewnętrznego misjonarze i diakoni są nieordynowanymi duchownymi. Ustawa o stosunku Państwa do Kościoła Chrześcijan Baptystów w Rzeczpospolitej Polskiej ${ }^{40}$ w art. 10a ust. 2 wskazuje,

\footnotetext{
${ }^{39}$ Zasadnicze Prawo Wewnętrzne Kościoła Chrześcijan Baptystów w Rzeczpospolitej Polskiej z 1.10.2005 r.; http://www.baptysci.pl/kosciol/akty-prawne/1460-zasadnicze-prawo-wewnetrzne. [dostęp: 15.1.2018 r.]

${ }^{40}$ Ustawa z 30.6.1995 r. o stosunku Państwa do Kościoła Chrześcijan Baptystów w Rzeczpospolitej Polskiej, Dz.U. z 2015 r., poz. 169.
} 
że osoba duchowna, przed którą składa się oświadczenia o zawarciu małżeństwa, określana jest przez Prawo Wewnętrzne Kościoła. Kwestia zawarcia małżeństwa wyznaniowego ze skutkami cywilnoprawnymi została uregulowana w Przepisach Prawnych Kościoła Chrześcijan Baptystów w Rzeczpospolitej Polskiej o formie zawarcia małżeństwa ${ }^{41}$. Artykuł 2 tej regulacji stanowi, że kobieta i mężczyzna w obecności duchownego oraz dwóch pełnoletnich świadków składają oświadczenia, że wstępują ze sobą w związek małżeński, który podlega prawu Kościoła Chrześcijan Baptystów w Rzeczpospolitej Polskiej, a jednocześnie zawierają małżeństwo podlegające prawu polskiemu. Nadto art. 8 określa kim jest duchowny odbierający oświadczenia woli; w myśl ustawy jest to pastor.

\subsection{Kościól Adwentystów Dnia Siódmego w RP}

Ustawą wyznaniową dla Kościoła Adwentystów Dnia Siódmego jest ustawa o stosunku Państwa do Kościoła Adwentystów Dnia Siódmego w Rzeczypospolitej Polskiej ${ }^{42}$. Kościół ten nie przyjął jednego aktu prawnego, który regulowałby podstawy funkcjonowania Kościoła. Za „prawo kościelne” uznaje się zbiór aktów składających się na adwentystyczne prawo kanoniczne w ogólności ${ }^{43}$. Należy do nich: Statut Kościoła Adwentystów Dnia Siódmego w Rzeczpospolitej Polskiej ${ }^{44}$, Prawo Generalnej Konferencji Kościoła Adwentystów Dnia Siódmego, Prawo Zborowe, Prawo Służby Kościelnej oraz uchwały organów Kościoła. Kwestie dotyczące osób duchownych uregulowane zostały poprzez przepisy Statutu i Prawa Zborowego. W Kościele tym brak jest stanu kapłańskiego w rozumieniu ogólnym, istnieje natomiast stan duchowny. W Kościele Adwentystów Dnia Siódmego istnieje wiele urzędów tj. starsi zboru, diakoni, nauczyciele, ewangeliści. Duchownym może zostać wyznawca wykazujący się powołaniem duchowym, heroizmem wiary i miłości, wysokim poziomem moralnym, należytym przygotowaniem teologicznym oraz gotowością poświęcenia się służbie Bożej. Duchowny ponadto powinien posiadać upoważnienie udzielone przez władzę kościelną ${ }^{45}$. Prawo Zborowe wyróżnia pastorów ordynowanych (ordained pastors), w Polsce zwanych starszymi i nieordynowanych (licensed pastors), określanych w Polsce

\footnotetext{
${ }^{41}$ Uchwała z 1.10. 2005 r. - Przepisy Prawne Kościoła Chrześcijan Baptystów w Rzeczpospolitej Polskiej o formie zawarcia małżeństwa; http://baptysci.pl/kosciol/akty-prawne/1811-przepisy-prawne-kosciola-chrzescijanbaptystow-w-rp-o-formie-zawarcia-malzenstwa. [dostęp: 15.1.2018 r.]

${ }^{4}$ Ustawa z 30.6.1995 r. o stosunku Państwa do Kościoła Adwentystów Dnia Siódmego w Rzeczypospolitej Polskiej, Dz.U. Nr 97 poz. 481.

${ }^{43}$ M. Osuchowska, Pojęcie duchownego..., s. 75.

${ }^{44}$ Statut Kościoła Adwentystów Dnia Siódmego w Rzeczpospolitej Polskiej z 12.6.2008 r.; https://adwent.pl/okosciele/statut/. [dostęp: 15.1.2018 r.]

${ }^{45}$ M. Osuchowska, Pojęcie duchownego..., s. 75.
} 
młodszymi. Starszy pastor, na mocy swojej ordynacji, ma prawo do odprawiania wszystkich nabożeństwa, obrzędów oraz ceremonii. Pastor młodszy może przemawiać, zachęcać do ewangelizacji, prowadzić działalność misyjną poza zborem oraz uczestniczyć we wszystkich działaniach zboru. Diecezja może powierzyć młodszemu duchownemu obowiązki pastora lub pomocnika pastora w danym zborze lub grupie zborów ${ }^{46}$. Ponadto w Prawie zborowym uregulowano, że „uroczystość ślubu, wraz z kazaniem, przyjęciem przysięgi małżeńskiej oraz ogłoszeniem zawarcia małżeństwa, może być prowadzona tylko przez pastora ordynowanego, za wyjątkiem sytuacji, gdy rada wydziału Generalnej Konferencji podejmie uchwałę upoważniającą wybranych pastorów nieordynowanych, posiadających jednak ordynację na urząd miejscowych starszych zboru, do przeprowadzenia takiej uroczystości ${ }^{47}$. Diakon nie może jednak przewodniczyć ceremonii ślubnych ${ }^{48}$. Pastor jako duchowny starszy, oprócz ordynacji, musi posiadać specjalne upoważnienie do dokonania czynności. Upoważnienie to, pomimo imiennego wskazania, nie ma charakteru terytorialności, w związku z czym pastor starszy może asystować przy zawieraniu związku małżeńskiego również poza terenem własnej parafiii ${ }^{49}$.

\subsection{Kościół Polskokatolicki w RP}

Prawa Wewnętrzne Kościoła Polskokatolickiego w RP z 27.6.1995 r. ${ }^{50}$ przyjmuje starokatolicką zasadę trójstopniowego Urzędu Apostolskiego. Urząd duchownego stanowią: diakoni, kapłani, biskupi (§ 28). Regulacja § 29 Prawa Wewnętrznego precyzuje, że święcenia udzielane są tylko mężczyznom ochrzczonym, których powołuje Bóg, natomiast zdolności wykonywania posługi w kościele zostały starannie rozwinięte w czasie studiów w Seminarium Duchownym $^{51}$. Diakonem jest mężczyzna, który otrzymał święcenia $\mathrm{z}$ rąk biskupa. Kapłanem natomiast jest ten, kto otrzymał święcenia kapłańskie z rąk biskupa ordynariusza lub z rąk biskupa przez niego wskazanego. Biskupem w Kościele Polskokatolickim jest kapłan wybrany przez Synod Ogólnopolski i konsekrowany przez trzech biskupów,

\footnotetext{
${ }^{46}$ M. Rakowski, Ł. Romanowski, A. Siciński (red.), Prawo Zborowe Kościoła Adwentystów Dnia Siódmego, Warszawa 2016, s. 33-34.

47 Tamże, s. 92.

48 Tamże, s. 98.

49 A. Mezglewski, Pojęcie ,,duchownego”..., s. 14.

${ }^{50}$ Prawo Wewnętrzne Kościoła Polskokatolickiego w Rzeczypospolitej Polskiej z 27.6.1995 r.; W. Wysoczański M. Pietrzak, Prawo kościołów i związków wyznaniowych nierzymskokatolickich w Polsce, Warszawa 1997, s. 171200.

${ }^{51}$ http://www.polskokatolicki.pl/RODZINA/2008_12/Kaplanstwo_w_Kosciele_Polskokatolickim.htm. [dostęp: 15.1.2018 r.]
} 
będących członkami Międzynarodowej Konferencji Biskupów Starokatolickich Unii Utrechckiej ${ }^{52}$. Analizowane przepisy nie wskazują na duchownego uprawnionego do asystowania przy zawarciu małżeństwa. Biorąc pod uwagę doniosłość zawarcia małżeństwa, należy uwzględnić również okoliczność, czy poza święceniami duchowny posiada odpowiednią władzę do odebrania od nupturientów oświadczenia woli o wstąpieniu w związek małżeński. Sam fakt święceń nie jest wystarczający do posiadania przez duchownego władzy jurysdykcyjnej; jest ona związana $\mathrm{z}$ pełnieniem określonej funkcji $\mathrm{w}$ Kościele. ${ }^{53}$ Stosunki między Państwem Polskim a Kościołem Polskokatolickim reguluje ustawa o stosunku Państwa do Kościoła Polskokatolickiego ${ }^{54}$.

\subsection{Gminy żydowskie $w$ RP}

Ustawa o stosunku Państwa do gmin wyznaniowych żydowskich w Rzeczpospolitej Polskiej ${ }^{55} \mathrm{w}$ art. 9a ust. 2 stanowi, że „osobę duchowną, przed którą składa się oświadczenia o zawarciu małżeństwa, określa prawo wewnętrzne gmin żydowskich”. Za podstawę prawa wewnętrznego należy uznać Statut Związku Gmin Wyznaniowych Żydowskich ${ }^{56}$. Akt ten nie posługuje się terminem „osoby duchownej”. W myśl art. 31 Statutu wszelkie funkcje religijne powierzone zostały rabinom i podrabinom, również udzielanie ślubów i rozwodów. Należy zatem domniemać, że właśnie wspominanych rabinów i podrabinów należy traktować jako duchownych uprawnionych do asystowania przy małżeństwie.

\subsection{Kościół Starokatolicki Mariawitów w RP}

Podobnie do wyżej wymienionych kościołów, ustawa wyznaniowa Kościoła Starokatolickiego Mariawitów ${ }^{57}$ wskazuje, że osobę duchowną, przed którą składa się oświadczenie o wstąpieniu w związek małżeński, określają normy prawa wewnętrznego Kościoła (art. 8a ust. 2). Prawem wewnętrznym, do którego odsyła przepis, jest Statut Kościoła

\footnotetext{
${ }^{52} \mathrm{http}$ //www.polskokatolicki.pl/HIERARCHIA/hierarchia.htm. [dostęp: 15.1.2018 r.]

${ }^{53}$ M. Osuchowska, Pojęcie duchownego..., s. 76.

${ }^{54}$ Ustawa z 30.6.1995 r. o stosunku Państwa do Kościoła Polskokatolickiego w Rzeczypospolitej Polskiej, tekst jedn. Dz.U. z 2014 r. poz. 1599

${ }^{55}$ Ustawa z 20.2.1997 r. o stosunku Państwa do gmin wyznaniowych żydowskich w Rzeczpospolitej Polskiej, Dz.U. Nr 41, poz. 251.

56 Statut Związku Gmin Wyznaniowych Żydowskich Rzeczpospolitej Polskiej z 6.12 .1992 r.; http://www.warszawa.jewish.org.pl. [dostęp: 15.1.2018 r.]

57 Ustawa z 20.2.1997 r. o stosunku Państwa do Kościoła Starokatolickiego Mariawitów w Rzeczpospolitej Polskiej, Dz.U. Nr 41, poz. 253.
} 
Starokatolickiego Mariawitów w RP z 26.4.1967 r. ${ }^{58}$. Działalność kościoła, w myśl art. II $§ 1$ Statutu, opiera się dodatkowo na zasadach Ustaw Kapłanów Mariawitów oraz prawie kanonicznym wydanym przez Kościół. W § 6 wymieniono natomiast urzędy kościelne należące do grona duchownych. Są nimi: Biskupi, Kapłani, Diakoni i Subdiakoni. Warto wspomnieć, że kandydatury na te stanowiska wymagają uzgodnienia $\mathrm{z}$ właściwymi władzami państwowymi, według art. II $§ 13$ Statutu. Dokument w swoich postanowieniach nie określa, jaki duchowny uprawniony jest do odebrania od nupturientów oświadczeń o zawarciu małżeństwa.

\subsection{Kościół Zielonoświątkowy w RP}

Ostatnim Kościołem mającym uregulowane stosunki z Rzeczpospolitą Polską jest Kościół Zielonoświątkowy. Norma wynikająca $z$ art. 11a ust. 2 ustawy wyznaniowej59 wskazuje, że osobę duchowną upoważnioną do odebrania oświadczeń woli od nupturientów określa Prawo Wewnętrze Kościoła. Prawo Wewnętrzne Kościoła Zielonoświątkowego w RP uchwalone zostało na Synodzie Nadzwyczajnym ${ }^{60}$. Do grona duchownych zalicza się diakonów i prezbiterów. Diakon, w myśl art. 38 ust. 3 Prawa Wewnętrznego, musi odpowiadać kwalifikacjom Pisma Świętego. Wówczas kandydat przechodzi co najmniej jednoroczny okres próbny. Po uzyskaniu pozytywnej opinii Rady Starszych i zdaniu egzaminu kościelnego może być ordynowany na diakona. Artykuł 38 ust. 5 Prawa Wewnętrznego upoważnia diakonów do wykonywania wszystkich czynności kościelnych, natomiast ust. 4 wymaga, by zostać prezbiterem należy mieć ukończone trzydzieści lat oraz co najmniej siedmioletni staż diakona. Prezydium Naczelnej Rady Kościoła, na wniosek Prezbitera Okręgowego, przeprowadza rozmowę kwalifikacyjną, a następnie podejmuje decyzję o powołaniu na prezbitera. Dodatkowo w art. 38 ust. 6 uznaje, że prezbiterzy są uprawnieni do wykonywania wszystkich czynności kościelnych oraz pełnienia wszelkich funkcji. Rozdział 11 Prawa Wewnętrznego w całości został poświęcony kwestii zawarcia małżeństwa. Małżeństwo zawarte przed duchowym wywołuje skutki cywilnoprawne, jeśli spełnia wymagania określone w Kodeksie rodzinnym i opiekuńczym oraz zostało zawarte zgodnie z Prawem Wewnętrznym.

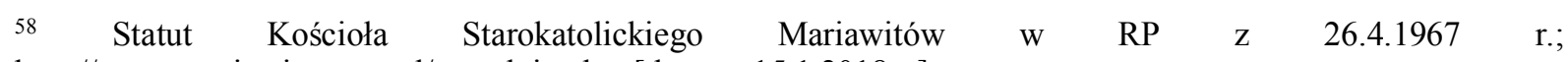
http://www.mariawita.waw.pl/czytelnia.php. [dostęp: 15.1 .2018 r.]

${ }^{59}$ Ustawa z 20.2.1997 r. o stosunku Państwa do Kościoła Zielonoświątkowego w Rzeczpospolitej Polskiej, Dz.U. z 2015 r. poz. 13.

${ }^{60}$ Prawo Wewnętrzne Kościoła Zielonoświątkowego w RP z 28.9.2007 r.; http://kz.pl/kzw/kosciol/prawowewnetrzne-kz/. [dostęp: 15.1.2018 r.]
} 
Artykuł 40 ust. 3 wyraźnie określa duchownego, który jest uprawniony do odebrania oświadczeń woli od nupturientów oraz duchownego-pastora, który podpisuje zaświadczenie o zawarciu małżeństwa niezbędne do wydania aktu małżeństwa.

\section{Podsumowanie}

Państwo Polskie reguluje stosunki jedynie z jedenastoma związkami wyznaniowymi (por. art. 25 Konstytucji). Ustawy regulujące stosunki między Państwem a kościołami i innymi związkami wyznaniowymi zawierają odwołanie do źródeł prawa wewnętrznego, nie we wszystkich kościołach pojęcia „duchownego” zostało zdefiniowane. Niektóre związki dokładnie wskazują duchownych uprawnionych do asystowania przy zawieraniu związku małżeńskiego, w innych dla ustalenia osób legitymowanych należy dokonać wykładni przepisów ogólnych. Określenie osoby mianem „duchownego” nie przesądza przy tym o prawie do odebrania oświadczeń woli od nupturientów. Rozstrzygniecie o jurysdykcji duchownego do przyjęcia oświadczeń woli od nupturientów o wstąpieniu w wyznaniowy związek małżeński ze skutkami cywilnoprawnymi bywa zatem sporne. Dodatkowo sprawę komplikuje fakt, że wymagane jest upoważnienie do określonych działań. Jednocześnie Kierownik Urzędu Stanu Cywilnego sporządzając akt małżeństwa opierać się może jedynie na zaświadczeniu od duchownego o zawarciu małżeństwa przez narzeczonych, a wątpliwości odnoszące się do osoby duchownego nie są postawą do odmowy sporządzenia dokumentu.

Wobec powyższego należałoby rozważyć możliwość ujednolicenia wykazu stanowisk osób uprawnionych do odbierania oświadczeń woli o zawarciu małżeństwa oraz sporządzeniu zaświadczenia do Urzędu Stanu Cywilnego, tak, by w sposób niebudzący wątpliwości można było ocenić ważność zawarcia związku małżeńskiego. 


\section{Summary}

The concept of the priest in provisions concerning obtaining civil effects through religious marriage

Marriage concluded in the presence of the priest is regulated in polish law system. The Republic of Poland There have implemented 11 acts regulating state relations with churches and religious associations acting on the polish territory. Those regulations allow to obtain civil effects through religious marriage, at the same time making the validity of marriage dependent on the authorization of the priest. The paper includes the analysis of the term "priest", explains who can effectively accept the declaration of will of the future spouses and issue marriage certificates to the Civil Registry Office.

\section{Katarzyna Bloch}

Studentka V roku prawa na Wydziale Prawa i Administracji UKSW. 